\title{
An analytical study of impact of merger \& acquisition on financial performance of corporate sector in India
}

\author{
Md Alam Ansari, ${ }^{1, *}$ M.Mustafa ${ }^{2}$ \\ ${ }^{1} \mathrm{PhD}$. Scholar, ${ }^{2}$ Ex Dean, School of Management Sciences, Lingaya's University, Faridabad, India \\ *Corresponding Author: \\ Email: alammanipal@gmail.com
}

\begin{abstract}
Merger and Acquisition is the most effective ways to accelerate the growth implementation plan of companies. All industries has been using M\&A as an aggressive strategy for growth. Merger and acquisition in is not a new concept and burst in M\&A has given further space to companies to look for integration for their growth, market coverage or any other strategic requirement.

The present research paper aims at studying the impact of mergers and acquisition on the financial performance of corporate sector in India. (On acquiring companies) For the purpose of analysis list of data of 6 companies has been considered from period 20122017.
\end{abstract}

The result suggested that there is no significant change on the financial performance of corporate sector in India after merger.

Keywords: Mergers, Acquisitions, Financial ratios, Post Merger.

\section{Introduction}

In M\&A acquired company deliberately delivers its Assets and Liabilities in the hands of acquiring company. Many companies choose to select integration with another entity to safeguard its business from downfall. Moving forward with M\&A with successful similar business is a winning strategy. ${ }^{10}$

The combined M\&A synergy of two companies is most suitable for the demand of the market and its stakeholders. The impact on shareholder may be negative or positive.

M\&A's provide tremendous opportunities for companies to grow and add value to stake holder's wealth. M\&A's increase value and efficiency and thereby increase holders value. M\&A's is a generic term used to represent many different types of corporate restructuring exercises Corporate executives foresee an acceleration of Merger and Acquisition activity in 2018 Technology and digital strategy being considered as an important factor for deals being pursued. In 2017 deal values increased by $53.3 \%$ to $\$ 77.6$ billion, compared with $\$ 50.6$ billion in 2016 Deal volumes rose by $2.5 \%$ to 614 deals in 2017 compared with 599 deals the previous year 2014, Indian companies were involved in transactions worth $\$ 33$ billion. $^{14}$

\section{Objectives of study}

1. To examine and evaluate the impact of mergers and acquisitions on the profitability position of the selected companies

2. To examine and evaluate the impact of mergers and acquisitions on the liquidity and leverage position of the companies

3. To suggest appropriate strategy for merger and acquisition of Indian industry.

\section{Research methodology and Source of Data}

Present study is primarily based on secondary data. The data were obtained from company's websites and published annual reports of companies. We have also referred websites such as Yahoo Finance, Money Control etc.

\section{Period of Study}

The study covers a period of five years from 2012 2017.

\section{Scope of the Study}

Present paper covers 06 companies as it was not possible for the researcher to consider all companies for study as the date will be huge, so a convenient sampling method and availability of required data has been considered as basic for selection of these companies.

\section{Data Analysis and Tools Used}

\section{About Sun Pharmaceutical Industries}

Sun Pharmaceutical is an India based pharmaceutical company having presence at the global level. It is the largest entity in Indian generic drug market. The company was founded in the year 1981 .

By the time Sun Pharmaceutical Industries acquired Ranbaxy in 2014 it has credit of successful acquisitions of 16 companies. The mega deal was target to make combined entity the 5th largest generic drug making company in the world.

It has a portfolio of more than 2,000 products with 50 manufacturing facilities cross the world. ${ }^{18}$

\section{About Vedanta Limited \\ Vedanta Limited, a Vedanta Group company is one of the world's largest global diversified natural resource}


majors, with operations across zinc-lead-silver, oil \& gas, iron ore, copper, aluminium and commercial power.

The company was founded in 1954 and since then it has grown to be one among the top low-cost producers of iron ore in the world. During 1991-1995, it diversified into the manufacture of pig iron and metallurgical coke. It has also developed indigenous and environmentfriendly technology for producing high quality metallurgical coke.

In 2007, it became a major subsidiary of Vedanta Resources Plc. ${ }^{20}$

\section{About JSW Energy}

JSW Energy has 3740 MW of operational generating capacity. In addition, it has power generation projects at an early stage under development with a proposed combined installed capacity of 8630 MW.JSW Energy, controlled by billionaire Sajjan Jindal, has acquired two of Jaiprakash Power Ventures' hydro power plants, with a combined capacity of $1,391 \mathrm{Mw}$, for Rs 9,700 crore. $^{19}$

\section{About Adani Ports}

Adani Ports and Special Economic Zone Limited (APSEZ) is India's largest private multi-port operator. It is a part of the Adani Group, an integrated infrastructure corporation. ${ }^{21}$

\section{About UltraTech Cement Limited}

UltraTech Cement Limited is an India cement company and India's largest exporter of cement and manufacturer which is based in Mumbai, India. The company has an installed capacity of 93 Million Tonnes Per Annum (MTPA) of grey cement. ${ }^{22}$

\section{About Lupin Limited}

Lupin Limited is a transnational pharmaceutical company based in Mumbai. It is the seventh-largest. Company by market capitalization and the 10th-largest generic pharmaceutical company by revenue globally. ${ }^{23}$

\section{Tools of Analysis \\ Ratio Analysis}

Ratios are among the well-known and most widely used tools of financial analysis. Ratio is the relationship between one items to another expressed in simple mathematical form. ${ }^{3-6}$

1. Gross Capital Employed Ratio

2. Net Capital Employed Ratio

3. Return on Long Term Funds Ratio

4. Gross Profit Ratio

5. Net Profit Ratio

6. Operating Profit Ratio

7. Earnings Per Share Ratio etc.

8. Current Ratio

9. Quick Ratio

10. Inventory Turnover Ratio
11. Debtors Ratio

12. Long Term Debt to Equity Ratio

13. Fixed Assets Turnover Ratio etc.

\section{Statistical Techniques}

Standard deviation Standard Deviation is also known as root mean square deviation for the reason that it is the square root of the mean of the squared deviation from arithmetic mean. ${ }^{4}$

Student t t-test $\mathrm{T}$ - test is based on $\mathrm{T}$ - Distribution and is considering an appropriate test for judging the significance of a sample mean. ${ }^{4}$

\section{Below is the result of Analysis (Table 01)}

1. Return on Gross Capital Employed: After mergers and acquisitions the financial performance of selected units was decreased except Adani Ports. The result shown by paired ' $t$ ' test reveals that the difference in return on gross capital employed is not significant After mergers and acquisitions the return on gross capital employed is not improved in selected units.

2. Return on Net Capital Employed: After mergers and acquisitions the financial performance of selected units was decreased except JSW Energy. The result shown by paired ' $t$ ' test reveals that the difference in return on net capital employed is not significant

3. Return on Share Holders Fund: After mergers and acquisitions the financial performance of selected units was decreased except JSW Energy Ltd. The result shown by paired' $t$ ' test reveals that the difference in return on shareholders' funds is not significant

4. Return on Long-term Funds: After mergers and acquisitions return on long term funds increased only for JSW Energy and Adani Ports.The result shown by paired ' $t$ ' test reveals that the difference in return on gross capital employed is not significant after mergers and acquisitions.

5. Earnings Per Share: After merger and acquisitions EPS increased for Adani, JSW Energy, Ultra Tech and Lupin Ltd The result hown by paired ' $t$ ' test reveals that the difference in EPS is not significant

6. Gross Profit Ratio: After mergers and acquisitions the financial performance of selected units was decreased except JSW, Ultra Tech and Lupin Ltd The result shown by paired ' $t$ ' test reveals that the difference in return on gross profit ratio is not significant.

7. Net Profit Ratio: After mergers and acquisitions the financial performance of selected units was decreased except JSW and Lupin Ltd.The result shown by paired ' $\mathrm{t}$ ' test reveals that the difference in return on net profit ratio is not significant

8. Operating Profit Ratio: After merger and acquisitions Operating Profit Ratio was decreased 
for all units except Lupin and JSW Energy. The ' $t$ ' test reveals that the difference in OPR is not significant

9. Current Ratio: After mergers and acquisitions the current ratio was decreased for Lupin, Adani \& JSW. The paired ' $t$ ' test reveals that the difference in current ratio is not significant

10. Quick Ratio: After mergers and acquisitions quick ration was decreased only for Sun Pharma and Vedanta. The result shown by paired ' $t$ ' test reveals that the difference in Quick ratio is not significant

11. Inventory Turnover Ratio: After mergers and acquisition inventory turnover ratio was increased in all the sample units except Adani Ports Ltd.The ' $t$ ' test reveals that the difference in ITR ratio is not significant

12. Debtors Ratio: The result shown by paired ' $t$ ' test reveals that the difference in Debtors ratio is not significant

13. Debt to Equity Ration: After mergers and acquisitions debt to equity ratio was decreased for all the units except Sun Pharma and Lupin Ltd. The result shown by paired ' $t$ ' test reveals that the difference in debt to equity ratio is not significant

14. Fixed Assets Turnover Ratio: After mergers and acquisitions the fixed assets turnover ratio was increased in three units The result shown by paired ' $t$ ' test reveals that the difference in Fixed Asset Turnover Ration is not significant

15. Owners Funds Ratio: The result shown by paired ' $t$ ' test reveals that the difference in owners funds ratio is not significant in the selected units, before and after mergers and acquisitions

16. Working Capital Turnover Ratio: After mergers and acquisitions the working capital turnover ratio was increased only for Sun Pharma The result shown by paired ' $t$ ' test reveals that the difference in owners funds ratio is not significant in the selected units, before and after mergers and acquisitions.

Table 1: Calculation of Financial Ratios

\begin{tabular}{|l|c|c|c|c|c|c|}
\hline \multirow{2}{*}{ Tools } & \multicolumn{2}{|c|}{ Pre-Merger } & \multicolumn{2}{c|}{ Post-Merger } & t-value & P value \\
\cline { 2 - 6 } & Mean & SD & Mean & SD & & \\
\hline Gross profit ratio & 58.78 & 4.84 & 57.38 & 5.65 & 1.12 & 0.46 \\
\hline Net profit ratio & 29.76 & 4.76 & 18.75 & 2.71 & 1.68 & 0.34 \\
\hline Operating profit ratio & 41.64 & 2.39 & 33.47 & 6.88 & 36.49 & 0.02 \\
\hline $\begin{array}{l}\text { Return on gross capital } \\
\text { employed }\end{array}$ & 24.29 & 0.09 & 19.15 & 1.83 & 2.73 & 0.22 \\
\hline $\begin{array}{l}\text { Return on net capital } \\
\text { employed }\end{array}$ & 25.52 & 0.66 & 21.58 & 1.68 & 4.03 & 0.15 \\
\hline Return on shareholders funds & 20.81 & 1.28 & 17.18 & 1.67 & 1.31 & 0.42 \\
\hline Return on long tern funds & 24.29 & 0.09 & 19.13 & 1.83 & 2.73 & 0.22 \\
\hline Owners fund ratio & 0.73 & 0.02 & 0.58 & 0.05 & 6.73 & 0.09 \\
\hline $\begin{array}{l}\text { Working capital turnover } \\
\text { ration }\end{array}$ & 1.19 & 0.19 & 1.79 & 0.42 & 6.29 & 0.1 \\
\hline Earning per share & 28.25 & 0.78 & 20.68 & 5.88 & 0.95 & 0.52 \\
\hline Current ratio & 3.85 & 0.12 & 2.27 & 0.62 & 11.16 & 0.06 \\
\hline Quick ratio & 3.04 & 0.13 & 1.83 & 0.54 & 14.58 & 0.04 \\
\hline Inventory turnover ratio & 4.11 & 0.38 & 4.74 & 0.32 & 2.11 & 0.28 \\
\hline Debtors ratio & 91.09 & 4.99 & 73.09 & 17.07 & 3.19 & 0.19 \\
\hline Long term debt to equity ratio & 0.37 & 0.03 & 0.73 & 0.14 & 6.83 & 0.09 \\
\hline Fixed asset to turnover ratio & 1.29 & 0.04 & 1.31 & 0.18 & 4.15 & 0.15 \\
\hline
\end{tabular}

Source: Researcher Own Calculation basis input data from Annual Reports of companies (data input) $)^{1,15-16}$

\section{Suggestions}

The profitability of Vedanta Ltd was very good before merger and acquisition, but after merger and acquisition it was decreased. So, these unit require concentrating on cost reduction system.

Vedanta, JSW Energy \& Ultra Tech Cement should improve their working capital by reducing its current liabilities. This will also improve their liquidity position.

There was drastic decrease in Net Profit of Vedanta Ltd, so its need to check how best it can reduce its expenses.
There was big downfall in ROCE of Lupin \& Sun Pharma, They need to check cost -benefit analysis before going ahead on capital investment.

Sun Pharma need to check its operating expenses as its operating profit decreased after merger.

\section{Conclusion}

The results and analysis of key financial ratios prior to Merger and post-Merger, and with above discussion it is evident that there was no significant effect on the business of the firm after Merger. Operating 
performance of companies was better prior to merger and acquisition. In terms of return on shareholders, it was better prior to merger.

\section{References}

1. Annual reports of companies, 2012-2017.

2. Chandra P., (2001), Financial Management, Tata- Mc Graw Hill Publication. Pp 69-105

3. Kaur, S., (2002), 'Ph.D. Thesis Abstract, A study of Corporate Takeovers in India, Submitted to University of Delhi, pp.1-11.

4. Pawaskar, V. (2001) Effect of Mergers on Corporate Performance in India. Vikalpa, Vol 26, No 1, January March, pp.19-32.

5. S.A. Siddiqui. Comprehensive Accountacy ( Part-IV), Laxmi Publications Pvt Ltd, pp-501-510

6. Surjit Kaur (2002): PhD Thesis Abstract, 'A study of corporate takeovers in India', submitted to University of Delhi, pp 1-11

7. https://mnacritique.mergersindia.com/sun-pharmaacquires-ranbaxy/

8. https://en.wikipedia.org/wiki/Economic_liberalisation_in _India

9. https://www.technoarete.org/common_abstract/pdf/IJSE M/v5/i2/Ext_41637.pdf

10. http://www.nishithdesai.com/fileadmin/user_upload/pdfs/ Ma\%20Lab/Sun_Pharma_-_Ranbaxy.pdf

11. https://www.ibef.org/industry/pharmaceuticalindia/showcase/ranbaxy

12. https://mnacritique.mergersindia.com/sun-pharmaacquires-ranbaxy/

13. http://www.ndtv.com/article/india/sun-pharma-toacquire-ranbaxy-in-4-billion-all-stock-deal-505205

14. http://gtw3.grantthornton.in/assets/Grant_Thornton_Annu al_dealtracker_2014.pdf

15. www.Moneycontrol.com

16. www.yahoofinance.com

17. https://en.wikipedia.org/wiki/Ranbaxy_Laboratories

18. https://en.wikipedia.org/wiki/Sun_Pharmaceutical

19. https://en.wikipedia.org/wiki/JSW_Energy

20. https://en.wikipedia.org/wiki/Vedanta_Limited

21. https://en.wikipedia.org/wiki/Adani_Ports_\%26_SEZ_Li mited

22. https://en.wikipedia.org/wiki/UltraTech_Cement

23. www.lupin.com 